\title{
The acquisition of grammatical gender in L2 German by learners with Afrikaans, English or Italian as their L1*
}

\author{
Carla Ellis, Simone Conradie \& Kate Huddlestone \\ Department of General Linguistics, Stellenbosch University, Private Bag X1, 7602 Matieland, South Africa \\ E-mail: ellisc@sun.ac.za; sconra@sun.ac.za; katevg@sun.ac.za
}

\begin{abstract}
In recent years there has been an increase in research on the acquisition of morphological aspects of a second language (L2). Specifically, a number of studies have been conducted on the acquisition of grammatical gender in the L2. The study reported in this paper investigated the adult L2 acquisition of grammatical gender in German by first language (L1) speakers of Afrikaans, English and Italian, respectively. The aim of the study was to determine how similarities and differences between the L1 and L2 in terms of grammatical gender affect the acquisition of this aspect of the target L2. Two experimental tasks - a picture naming task and a sentence completion task - were designed to determine to what extent the grammatical gender of nouns is accurately reflected on determiners and adjectives. Throughout, the L1 Italian group outperformed the other two groups. Since Italian (like German) expresses grammatical gender on determiners and nouns, while neither English nor Afrikaans does, the results indicate that the acquisition of grammatical gender in an L2 is easier for learners whose L1 also expresses grammatical gender. Specifically, the results provide evidence for so-called "deep transfer" (transfer of abstract grammatical properties) from the L1 to the L2 in this area of L2 acquisition: since the grammatical gender systems of Italian and German are not congruent, the Italian speakers' advantage over the other two L1 groups cannot be the result of simple "surface transfer" (transferring knowledge of the grammatical gender of specific nouns in the L1 to the L2) and must be attributed to deep transfer.
\end{abstract}

Keywords: adult second language acquisition; first language transfer; grammatical gender

\section{Introduction}

Throughout the past few decades a wealth of research on second language (L2) acquisition has focused on the role of the learner's first language (L1) (Clahsen and Muysken 1986; White 1989; Schwartz and Sprouse 1996; Vainikka and Young-Scholten 1996; Slabakova 2000; Sabourin 2001; Juffs 2005). In recent years there has also been an increase in research on the acquisition of morphological aspects of the target L2; specifically, a number of studies have been conducted on the acquisition of grammatical gender in the L2 - see, for example, Hawkins and Franceschina 2004; White, Valenzuela, Kozlowska-MacGregor and Leung 2004; Franceschina 2005; Sabourin, Stowe and De Haan 2006; Blom, Polišenská and Unsworth 2008; Blom, Polišenská and Weerman 2008; Cornips and Hulk 2008; and Unsworth 2008. The study

\footnotetext{
* This paper is based on Carla Ellis' (2011) Master's thesis, supervised by Simone Conradie and Kate Huddlestone.
} 
reported in this paper investigated the acquisition of grammatical gender in L2 German by adult L1 speakers of Afrikaans, English and Italian, respectively.

According to Levelt et al. (1999, in Salamoura 2007:100), grammatical gender is an inherent quality of a noun, and it is stored in the relevant noun's entry in the lexicon. Grammatical gender is a complex linguistic category, and it is challenging for learners to master this property of an L2. The structure of the L1 evidently plays an important role in this regard. Several studies suggest that transfer from the L1 can assist in L2 acquisition when the L1 and L2 are similar in terms of the relevant property and that this is also true for grammatical gender (Sabourin et al. 2006:2). A distinction is made between two types of transfer, namely surface transfer and deep transfer (cf. Sabourin, Stowe and De Haan 2006). We will describe the two types of transfer with reference to the grammatical property under discussion in this paper, namely grammatical gender. Surface transfer is possible when the grammatical gender system of the L1 is congruent to that of the target L2; for example, when both the L1 and the L2 have two grammatical genders - masculine and feminine - and all/most of the nouns that are feminine in the L1 are feminine in the L2, and all/most of the nouns that are masculine in the L1 are masculine in the L2.

When the grammatical gender system of the L1 is not congruent to that of the target L2, then surface transfer cannot occur; for example, when the L1 has two genders - masculine and feminine - and the target L2 has three genders - masculine, feminine and neuter - and there is no clear correlation between nouns that are masculine in the L1 and nouns that are masculine in the target L2 or between nouns that are feminine in the L1 and nouns that are feminine in the target L2. The question is whether so-called "deep transfer" can occur in cases such as these where surface transfer is not possible. Here, "deep transfer" refers to the transfer of an abstract grammatical feature (such as grammatical gender) from the L1 to the L2.

Keeping this in mind, consider the examples in (1) to (4) below:

(1) German

FEMININE die (schöne) Frau "the (beautiful) woman"; eine (schöne) Frau "a (beautiful) woman"

MASCULINE der (schöne) Regenschirm "the (beautiful) umbrella"; ein (schöner) Regenschirm "a (beautiful) umbrella"

NEUTER das (schöne) Auto "the (beautiful) car"; ein (schönes) Auto "a (beautiful) car"

PLURAL (ALL NOUNS) die (schönen) Frauen, Regenschirmen, Autos

(2) Italian

FEMININE la (bella) macchina "the (beautiful) car"; una (bella) macchina "a (beautiful) car"

MASCULINE il (bell') ombrello "the (beautiful) umbrella"; un (bell') ombrello "a (beautiful) umbrella"

PLURAL (F) le (belle) macchine

PLURAL (M) I (begli) ombrelli

(3) English

ALL NOUNS the (beautiful) woman, man, umbrella, car, etc.

a (beautiful) woman, man, umbrella, car, etc.

PLURAL (ALL NOUNS) the (beautiful) women, men, umbrellas, cars, etc. 
(4) Afrikaans

ALL NOUNS die (mooi) vrou, man, sambreel, kar, etc. "the (beautiful) woman, man, umbrella, car, etc."

'n (mooi) vrou, man, sambreel, kar, etc. "a (beautiful) woman, man, umbrella, car, etc."

PLURAL (ALL NOUNS) die (mooi) vrouens, mans, sambrele, karre, etc.

If one looks at the determiners and adjectives in these examples, one can see that their form is determined by the grammatical gender of the noun in German and Italian. In German and Italian every noun has a grammatical gender feature. In German this feature is either masculine or feminine or neuter, and in Italian it is either masculine or feminine. The grammatical gender of a noun is reflected in the form of definite and indefinite determiners, as well as adjectives. In contrast, nominal expressions in Afrikaans and English do not display grammatical gender, as is illustrated by the fact that every noun in Afrikaans takes the same form of the indefinite determiner (' $n$ ), the same form of the definite determiner (die) and the same form of any particular adjective. In English there is one single form of the definite determiner (the) for every noun, an adjective takes exactly the same form for every noun, and there are only two forms of the indefinite determiner $-a$ and $a$, the choice of which is determined by whether the following word (adjective or noun) starts with a vowel (an) or a consonant $(a)$. The aim of the study reported here was to determine how such similarities and differences between the L1 (Afrikaans, English and Italian) and the L2 (German) in terms of grammatical gender (the morphological presence vs. absence of it, as well as how it is phonetically realised) affect the acquisition of this aspect of the target L2.

In the case of English and Afrikaans, there can be neither surface transfer nor deep transfer since neither the phonetic realisation of grammatical gender nor the abstract feature of grammatical gender can be transferred from the L1 (because the two languages do not have grammatical gender).

In the case of Italian, surface transfer is not possible since the grammatical gender system of Italian is not congruent to that of the target L2, German, as explained above. The question is thus whether deep transfer (transfer of the abstract feature of grammatical gender) can occur in this case. If deep transfer occurs, Italian-speaking learners of German should have an advantage over English- and Afrikaans-speaking learners of German in terms of the acquisition of grammatical gender. If deep transfer does not occur, no such advantage should be found for the Italian-speaking learners.

Our first research question was thus whether Italian-speaking learners of German would acquire grammatical gender more successfully than English- and Afrikaans-speaking learners, even though grammatical gender is (taxonomically and phonetically) represented differently in Italian than in German.

Our second research question relates to the fact that Afrikaans and German are very similar in terms of vocabulary and syntax. We were interested in whether Afrikaans-speaking learners of German would acquire grammatical gender more successfully than English-speaking learners, given that even though neither English nor Afrikaans has grammatical gender, Afrikaans is very similar to German in terms of vocabulary and syntax. Could similarity in vocabulary and syntax really lead to a "lighter burden" for Afrikaans-speaking learners of German to such an extent 
that it makes the acquisition of grammatical gender easier for Afrikaans-speaking learners than for English-speaking learners?

\section{Participants}

A total of 38 students participated in the study: 23 with L1 Afrikaans, nine with L1 English and six with L1 Italian, all of whom grew up speaking only their L1 at home. Of course, the discrepancy between the sizes of the different L1 groups is not at all ideal - this was due to practical problems with recruiting participants. However, this was taken into consideration during statistical testing.

The participants' ages ranged from 18 to 24 years. At the time of testing they had all received only one year of exposure to and instruction in L2 German, so they were all adult L2 learners. All of the participants had completed a first-year course in German for beginners: the Afrikaans and English speakers at Stellenbosch University, and the Italian speakers at a university in Italy.

\section{Tasks and results}

Data were collected by means of two experimental tasks, namely a picture naming task, and a sentence completion task. In order to ensure that learners knew all of the vocabulary items used in the tasks, the vocabulary was kept very basic and learners also received a word list of all of the German vocabulary items used in the tasks with their Afrikaans, English and Italian translations (of course, without determiners, so as not to give away the grammatical gender of nouns) (see Appendix A).

These tasks (based on those of Orgassa and Weerman 2008) were designed to determine to what extent the grammatical gender of nouns is accurately reflected on determiners and adjectives in the written L2 production of the participants. In order to avoid repetition, we will present the results for each task immediately after the task has been described.

The picture naming task involved a total of 18 items, consisting of five masculine (der) nouns, five feminine (die) nouns, five neutral (das) nouns, and three plural (die) nouns, with items distributed randomly in terms of grammatical gender (see Appendix B). The task was designed to test gender assignment. The participants were asked to fill in the appropriate determiner (der/die/das) in the space provided - see the example in (5) below, for which the participant had to fill in das, given that Haus is a neuter noun.

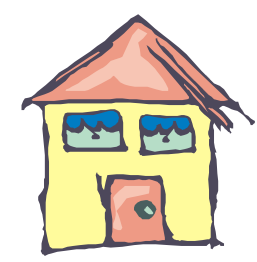

Haus

The results of this task are presented in Table 1. For each of the L1 groups (Afrikaans, English, and Italian) it is indicated for what percentage of items in each category (masculine, feminine, neuter and plural) they provided the correct determiner. 
Table 1. Group results for the picture naming task (gender assignment)

\begin{tabular}{|l|l|l|l|l|l|}
\hline & Masculine & Feminine & Neuter & Plural & TOTAL \\
\hline English & $73.3 \%$ & $68.8 \%$ & $64.4 \%$ & $51.80 \%$ & $66.04 \%$ \\
\hline Afrikaans & $73.9 \%$ & $73.04 \%$ & $63.47 \%$ & $72.46 \%$ & $70.50 \%$ \\
\hline Italian & $73.3 \%$ & $86.7 \%$ & $66.7 \%$ & $100 \%$ & $79.6 \%$ \\
\hline p-value & 0.999 & 0.25 & 0.97 & $\mathbf{0 . 0 1 1} \%$ & 0.285 \\
\hline
\end{tabular}

As can be seen in the last row of Table 1, non-parametrical statistical tests showed that the only significant difference between the three groups was in terms of their performance on plural items: here, the Italian group performed significantly better than both of the other groups $(\mathrm{p}=$ 0.011 ), as all participants provided the correct determiner $100 \%$ of the time. This is not surprising, given that Italian has a more complex plural system than German - recall the examples in (1) and (2): in Italian there are different forms of the determiner and the adjective depending on the grammatical gender of the noun; in German all plural nouns get the same form of the determiner and the adjective. Therefore, it might well be that the Italian-speaking learners have noticed that German is "easy/straightforward" in this respect - all plural nouns take the determiner die. Although it is interesting that the other two groups do not seem to have noticed this, the most important result is that there was no significant difference between the three groups in terms of gender assignment (i.e. deciding whether a noun is masculine, feminine or neuter) in this task. In addition, no significant differences between item types (masculine, feminine, neuter and plural) were found for the Afrikaans or the English group. Only one significant difference between item types was found for the Italian group: they fared significantly better on the plural items than on any of the other item types $(p=0.025)$.

The sentence completion task was designed to test for gender agreement rather than gender assignment because participants were asked to fill in the appropriate form of the determiner and the adjective in 16 sentences (see Appendix C). They had to do this based on the preceding German sentence (in which the grammatical gender of the noun was provided), as well as the Afrikaans, English or Italian translation of the determiner and adjective, given in brackets. An example of a test item is provided in (6) below. The participant is given the German sentence Das Mädchen ist schön ('the girl is beautiful') from which it is clear that the noun Mädchen is neuter (as it is preceded by the determiner das). The participant is then asked to provide the correct German form of the determiner $a$ and the adjective beautiful in the next sentence (Ich liebe (a beautiful) Mädchen. 'I love (a beautiful) girl.'). In this case, the correct response would be ein schönes because Mädchen is a neuter noun, ein is the appropriate form of an indefinite determiner preceding a neuter noun, and schönes is the appropriate form of this particular adjective when it precedes a neuter noun.

Das Mädchen ist schön. Ich liebe (a beautiful) Mädchen.

Four nouns (feminine Frau, masculine Baum, neuter Mädchen, and plural Bücher) appeared in four sentences each, requiring the correct form for a determiner and an adjective in four different conditions: (i) definite nominative, (ii) definite accusative, (iii) indefinite nominative, and (iv) indefinite accusative - see (7) below.

(7) Categorisation of responses (per participant) on the sentence completion task:

DEF, NOM $\quad \mathrm{n}=8(\mathrm{M}, \mathrm{F}, \mathrm{N}, \mathrm{PL} \operatorname{det}$ and $\mathrm{M}, \mathrm{F}, \mathrm{N}, \mathrm{PL}$ adj)

DEF, ACC $\quad n=8(M, F, N$, PL det and M, F, N, PL adj) 
$\begin{array}{ll}\text { INDEF, NOM } & n=7(M, F, N \text { det and M, F, N, PL adj) } \\ \text { INDEF, ACC } & n=7(M, F, N \text {, det and M, F, N, PL adj) }\end{array}$

For this task, we were interested in six categories of responses: definite, indefinite, nominative, accusative, determiners and adjectives. The results for these six categories are provided for each L1 group in Table 2 below, as percentage of correct responses.

Table 2. Group results for the sentence completion task (gender agreement)

\begin{tabular}{|l|l|l|l|l|l|l|c|}
\hline & DEF & INDEF & NOM & ACC & DET & ADJ & TOTAL \\
\hline English & $50.7 \%$ & $42.9 \%$ & $47.4 \%$ & $46.7 \%$ & $49.2 \%$ & $45.1 \%$ & $47.04 \%$ \\
\hline Afrikaans & $58.7 \%$ & $49.4 \%$ & $57.4 \%$ & $51.3 \%$ & $51.2 \%$ & $57.1 \%$ & $54.35 \%$ \\
\hline Italian & $69.8 \%$ & $73.8 \%$ & $73.3 \%$ & $70.0 \%$ & $78.6 \%$ & $65.6 \%$ & $71.67 \%$ \\
\hline p-value & 0.171 & $\begin{array}{c}\mathbf{0 . 0 1 2} \\
\text { I }>\text { A } \\
\text { I }>\text { E }\end{array}$ & $\begin{array}{c}\mathbf{0 . 0 4 9} \\
\text { I }>\text { E }\end{array}$ & 0.052 & $\begin{array}{c}\mathbf{0 . 0 1 1} \% \\
\text { I }>\mathbf{A} \\
\text { I }>\mathbf{E}\end{array}$ & 0.192 & $\begin{array}{c}\mathbf{0 . 0 3 3} \\
\text { I }>\text { E }\end{array}$ \\
\hline
\end{tabular}

As can be seen in the last row of Table 2, non-parametrical statistical tests indicated that there were significant differences between the three L1 groups for three of the six categories, namely indefinite, nominative and determiner, as well as for their overall performance on the task (see "TOTAL"). Specifically, the Italian group performed significantly better than both the Afrikaans and the English group in the categories indefinite and determiner, and the Italian group performed significantly better than the English group in the category nominative and in the task overall.

Despite the fact that there are so few statistically significant differences between the three groups, there is a very clear pattern here: the Italian group outperformed the Afrikaans and English groups in every single category of this task, and the Afrikaans group similarly outperformed the English group (cf. Table 2: Italian $>$ Afrikaans $>$ English in every single category, even though not all of these between-group differences are statistically significant). Section 4 below provides a brief discussion of these results.

\section{Discussion}

The results of the picture naming task showed that there were no significant differences between the three L1 groups in terms of gender assignment. Specifically, the Italian group did not have an advantage over the other two groups even though this is the only one of the three L1s that, like the target L2, has grammatical gender. This is unsurprising because only surface transfer would be facilitative in terms of actual gender assignment (i.e. deciding whether a noun is feminine, masculine or neuter) and surface transfer is not possible here because the grammatical gender system of the L1 Italian is not congruent to that of the target L2 German.

Turning to the sentence completion task and the issue of gender agreement: although there were very few statistically significant differences between the three groups in the sentence completion task, there was a very clear Italian $>$ Afrikaans $>$ English pattern in that the Italian group consistently outperformed the Afrikaans group which, in turn, consistently outperformed the English group. This pattern provides an answer to our first research question in that it indicates an advantage for Italian speakers over Afrikaans and English speakers. Italianspeaking learners of German do seem to acquire grammatical gender more successfully than English-speaking and Afrikaans-speaking learners. The most straightforward explanation for 
this is the fact that Italian, like the target L2 German, has grammatical gender, whereas English and Afrikaans do not. Furthermore, since the grammatical gender system of Italian is not congruent to that of German, it cannot be surface transfer that is facilitating the acquisition of grammatical gender in this case. It must be deep transfer. Consequently, the pattern provides evidence for deep transfer.

In answer to our second research question, the consistent Afrikaans $>$ English pattern indicates an advantage for Afrikaans speakers over English speakers in the acquisition of grammatical gender in German. The most straightforward explanation for this is the similarity between Afrikaans and German in terms of vocabulary and syntax. It seems that this similarity really does lead to a "lighter burden" for Afrikaans-speaking learners of German to such an extent that it makes the acquisition of grammatical gender in L2 German easier for Afrikaans-speaking than for English-speaking learners, even though neither of the two L1s has grammatical gender. Of course, it might well be that there is another explanation for the Afrikaans advantage, but such an alternative explanation is not obvious to us, especially given that the Afrikaans- and English-speakers had all received the same L2 German instruction in the same classes from the same lecturers for the same amount of time.

In future research it would be ideal to have larger groups and to also have an equal number of participants in each group. This is, of course, a quite serious limitation of the study reported here and may well have contributed to the lack of statistically significant differences between the groups, despite the very clear patterns referred to above. Furthermore, valuable insights could be gained by tracking the progress of learners with these three L1s, in terms of their acquisition of grammatical gender in L2 German, to see up to which point in development (i) the Italian group would have an advantage over the other two groups, and (ii) the Afrikaans group would have an advantage over the English group.

To conclude, the results of the study reported in this paper provide evidence for the occurrence of deep transfer in the acquisition of grammatical gender in L2 German. Although this was a small scale study, it does contribute to research being conducted internationally on the L2 acquisition of grammatical gender, and it is the first such study to include Afrikaans. We hope that the study will encourage further, more in-depth research on this topic and that will also include other African languages.

\section{References}

Blom, E., D. Polišenská and S. Unsworth. 2008. The acquisition of grammatical gender in Dutch. Second Language Research 24(3): 259-265.

Blom, E., D. Polišenská and F. Weerman. 2008. Articles, adjectives and age of onset: the acquisition of Dutch grammatical gender. Second Language Research 24(4): 297-331.

Clahsen, H. and P. Muysken. 1986. The availability of Universal Grammar to adult and child learners: A study of the acquisition of German word order. Second Language Research 2: 93-119.

Cornips, L. and A. Hulk. 2008. Factors of success and failure in the acquisition of grammatical gender in Dutch. Second Language Research 24(4): 267-295.

Ellis, C. 2011. Die verwerwing van grammatikale geslag in tweedetaal Duits deur leerders met Afrikaans, Engels of Italiaans as eerstetaal. Unpublished MA thesis. Stellenbosch University.

Franceschina, F. 2005. Fossilised second language grammars: the acquisition of grammatical gender. Amsterdam: John Benjamins. 
Hawkins, R. and F. Franceschina. 2004. Explaining the acquisition of and non-acquisition of determiner-noun gender concord in French and Spanish. In P. Prévost and J. Paradis (eds.) The acquisition of French in different contexts: focus on functional categories. Amsterdam: John Benjamins. pp. 175-205.

Juffs, A. 2005. The influence of first language on the processing of wh-movement in English as a second language. Second Language Research 21: 121-151.

Orgassa, A. and F. Weerman. 2008. Dutch gender in specific language impairment and second language acquisition. Second Language Research 24(4): 333-364.

Sabourin, L. 2001. L1 effects on the processing of grammatical gender in L2. In S.H. FosterCohen and A. Nizegorodcew (eds.) EUROSLA Yearbook 2001. pp. 159-69.

Sabourin, L., L.A. Stowe and G.J. de Haan. 2006. Transfer effects in learning a second language grammatical gender system. Second Language Research 22: 1-29.

Salamoura, A. 2007. Grammatical gender in the bilingual lexicon: A psycholinguistic approach. In I. Kecskes en L. Albertazzi (eds.) Cognitive Aspects of Bilingualism. Berlin: Springer Verlag. pp. 99-151.

Schwartz, B.D. and R.A. Sprouse. 1996. L2 cognitive states and the Full Transfer/Full Access model. Second Language Research 12(1): 40-72.

Slabakova, R. 2000. L1 transfer revisited: the L2 acquisition of telicity marking in English by Spanish and Bulgarian native speakers. Linguistics 38: 739-770.

Unsworth, S. 2008. Age and input in the acquisition of grammatical gender in Dutch. Second Language Research 24(3): 365-395.

Vainikka, A. and M. Young-Scholten. 1996. Gradual development of L2 phrase structure. Second Language Research 12: 7-39.

White, L. 1989. Universal Grammar and second language acquisition. Amsterdam: John Benjamins Publishing Company.

White, L., E. Valenzuela, M. Kozlowska-MacGregor and Y.-K.I. Leung. 2004. Gender and number agreement in nonnative Spanish. Applied Psycholinguistics 25: 105-33.

\section{Appendix A \\ Vocabulary List}

\section{GERMAN}

alt

Auto

Baum

Blume

Bücher

Fenster

Fernseher

groß

Haus

Hose

interessant

Junge

Kinder

Kleid

Messer
AFRIKAANS

oud

kar

boom

blom

boeke

venster

televisie

groot

huis

broek

interessant

seun

kinders

rok

mes
ENGLISH

old

car

tree

flower

books

window

television

big

house

pants

interesting

boy

children

dress

knife
ITALIAN

vecchio

macchina

albero

fiore

libri

finestra

televisore

grande

casa

pantaloni

interessante

ragazzo

bambini

vestito

coltello 


$\begin{array}{llll}\text { Radio } & \text { radio } & \text { radio } & \text { radio } \\ \text { Regenschirm } & \text { sambreel } & \text { umbrella } & \text { ombrello } \\ \text { schön } & \text { mooi } & \text { beautiful } & \text { bello } \\ \text { schwarz } & \text { swart } & \text { black } & \text { nero } \\ \text { Sonne } & \text { son } & \text { sun } & \text { sole } \\ \text { Studenten } & \text { studente } & \text { students } & \text { studenti } \\ \text { Stuhl } & \text { stoel } & \text { chair } & \text { sedia } \\ \text { Tür } & \text { deur } & \text { door } & \text { porta } \\ \text { Zeitung } & \text { koerant } & \text { newspaper } & \text { giornale } \\ \text { Zug } & \text { trein } & \text { train } & \text { treno }\end{array}$

\title{
Appendix B
}

Picture Naming Task: Vocabulary for Test Items

All 18 words were taken from a beginner's handbook of German. To ensure that the students understood the instructions, they were given an example at the beginning. The words below are paired together according to their grammatical class. In the actual task, they were distributed randomly.

(1) MASCULINE

\author{
der Fernseher 'television' \\ der Junge 'boy' \\ der Regenschirm 'umbrella' \\ der Stuhl 'chair' \\ der Zug 'train'
}

(2)

\section{FEMININE}

die Blume 'flower'

die Hose 'pants'

die Sonne 'sun'

die Tür 'door'

die Zeitung 'newspaper'

(3)

NEUTER

das Auto 'car'

das Fenster 'window'

das Haus 'house'

das Kleid 'dress'

das Radio 'radio'

(4) PLURAL die Bücher 'books'

die Kinder 'children'

die Studenten 'students' 


\section{Appendix C}

Sentence Completion Task: Test Items

(1) Die Frau ist alt.

Das ist (the old) Frau.

Correct answer: Das ist die alte Frau.

(F, def DET, NOM)

(2) Das Mädchen ist schön.

Ich liebe (the beautiful) Mädchen.

Correct answer: Ich liebe das schöne Mädchen.

(N, def DET, ACC)

(3) Der Baum ist groß.

Das ist (a big) Baum.

Correct answer: Das ist ein großer Baum.

(M, indef DET, NOM)

(4) Die Frau ist alt.

Er kennt (an old) Frau.

Correct answer: Er kennt eine alte Frau.

(F, indef DET, ACC)

(5) Das Mädchen ist schön.

Das ist (the beautiful) ___ Mädchen.

Correct answer: Das ist das schöne Mädchen. $\quad$ (N, def DET, NOM)

(6) Die Bücher sind interessant.

Das sind (interesting) ___ Bücher.

Correct answer: Das sind interessante Bücher. $\quad$ (PL, no DET, NOM)

(7) Die Frau ist alt.

Er kennt (the old) __ Frau.

Correct answer: Er kennt die alte Frau.

(F, def DET, ACC)

(8) Der Baum ist groß.

Das ist (the big) Baum.

Correct answer: Das ist der große Baum.

(M, def DET, NOM)

(9) Das Mädchen ist schön.

Ich liebe (a beautiful) Mädchen.

Correct answer: Ich liebe ein schönes Mädchen.

(N, indef DET, ACC)

(10) Die Bücher sind interessant.

Die Studenten lesen (the interesting)

Bücher.

Correct answer: Die Studenten lesen die interessanten Bücher.

(11) Die Frau ist alt.

Das ist (an old) Frau.

Correct answer: Das ist eine alte Frau.

(F, indef DET, NOM) 
(12) Die Bücher sind interessant.

Die Studenten lesen (interesting)

Bücher.

Correct answer: Die Studenten lesen interessante Bücher. (PL, no DET, ACC)

(13) Der Baum ist groß.

Ich sehe (the big) Baum.

Correct answer: Ich sehe den großen Baum.

(M, def DET, ACC)

(14) Das Mädchen ist schön.

Das ist (a beautiful) Mädchen.

Correct answer: Das ist ein schönes Mädchen.

(N, indef DET, NOM)

(15) Der Baum ist groß.

Ich sehe (a big) Baum.

Correct answer: Ich sehe einen großen Baum.

(M, indef DET, ACC)

(16) Die Bücher sind interessant.

Das sind (the interesting) Bücher.

Correct answer: Das sind die interessanten Bücher.

(PL, def DET, NOM) 